\title{
DRINKING WATER QUALITY IN SOME SELCTED SLUMS OF DHAKA CITY, BANGLADESH
}

\author{
Subrata Chowdhury \\ Department of Civil Engineering \\ Stamford University Bangladesh, Dhaka, Bangladesh
}

\begin{abstract}
Over the last decade, Dhaka city of Bangladesh has experienced significant changes throughout its landscape and an extreme growth in population. As a result of environmental, economic, or demographic crises, Pressure increase on housing due to rapid urbanization and rural urban migration causes growth of slums and squatter settlements. Slums are residential areas of very high population density, high room density and poor housing with inadequate access to basic civic amenities. The specific objectives of the study are to explore the to investigate the existing water supply facilities and to know the drinking water quality of selected slums in Dhaka city. Korail slum and Geneva Camp slum have been randomly selected. Overall environment of the slum areas is disappointing due to unplanned housing, drains, roads and different authorized \& unauthorized shops. The chemical quality of drinking water is satisfactory but microbiological quality of water is not up to the standard of drinking water. Due to the involvements of the Government, DWASA, and other national and international Non-Government Organization (NGO) s, the slums are getting access to pure drinking water supply although these are still insufficient.
\end{abstract}

\section{Keywords_- Drinking water, Hygiene, Slum, Quality}

\section{INTRODUCTION}

Water, which is now more precious than ever in our history, and is essential for almost all the sectors related to human survival that includes agriculture, forestry, industries, navigation, fisheries, drinking and sanitation and mining etc. With decreasing availability and increasing demand for water, some have predicted that clean water will become the "next oil" in world (Rahaman, 2012). Bangladesh is under serious freshwater crisis especially in the urban areas. Both the availability and the quality of water are decreasing in the poor urban areas. Besides, the population situation of the country is getting worst in Dhaka, which became one of the mega cities in the world in terms of population and urbanization. The percentage of slum population within the overall population has increased from 25 percent in 1996 to 37.4 percent in 2007 occupying an area of only 4 percent of the total Dhaka Metropolitan Area (DMA) [UN, 2012] In Bangladesh, every year almost 3 million children under five years of age die of diarrheal disease and every child suffers and average of three times diarrheal attacks in a year (Badhan et al 2017). It is recommended that diarrheal diseases can be prevented easily with the use of safe water and hygienic sanitation (WHO, 2000). In many areas the sanitation coverage is much below the national coverage figure, only $13.5 \%$ in metropolitan slum (USAID, 1999).

Dhaka, the capital and also the primate city of the country, grows at nearly 5 per cent annually. Rapid urban growth in Bangladesh has been created adverse effects on different sectors. Some adverse effects are mass poverty, increase of slums and squatters, inadequate supply of urban facilities such as water electricity, solid waste disposal, sanitation, sewerage, fuel or cooking etc. and degradation of social, neighborhood and physical environment. Mainly the poor in the slums are deprived from all urban facilities. Most of the people live below the poverty line in the slums and they all are deprived from the urban facilities according to the demand. The water supply and sanitation situation in the slum areas of Dhaka city is very poor. The water supply coverage in the slums is about $69 \%$, the sanitary latrines coverage is only $48 \%$ (CBSG 2010). The crisis of water supply and quality of drinking water are common features in daily life of slum people of Dhaka city. So, it is an immediate concern to study and assess the present scenario of drinking water qualities for slum dwellers in this city.

\section{POVERTY AND FACILITIES IN SLUMS OF DHAKA CITY}

The slum population in Dhaka City faces extreme poverty due to its low level of earnings and the majority are living below the poverty line in terms of both calorie intake and cost of basic needs. The slum dwellers are mostly involved in low paid jobs in informal sectors of the urban economy. To be precise there is a predominance of day laboring and rickshaw pulling among this poor group of city dwellers (Amin A.T.M.N., (1991). About 68\% of slum families in Dhaka City have a single room unit, $20 \%$ have two small rooms and at least $5 \%$ have to share a room with other families (CUS, 1979). The average floor spaces of poor urban households are only $125 \mathrm{sq}$. $\mathrm{ft}$, with only 100 sq. ft in Dhaka City (Islam et. al., 1997). Slum dwellers in 
the city are disadvantaged in terms of their access to urban services like safe water, electricity, gas supply, toilet facilities and garbage disposal. The quality of these services has been found to be poor and the supply remains highly irregular and inadequate (CUS, 1993). Most slum dwellers have access to safe water for drinking purpose only. And most use unsafe water for washing, bathing and other purposes. A small proportion of the urban poor $(20 \%)$ use sanitary latrines and the majority still use a variety of non-hygienic latrines (CUS 1996). Slum populations have limited access to health and education. Though theoretically the urban poor have equal access to the public health facilities in the city, in reality very little are available to them (Farid Uddin et.al, 1996).

Table 1 reveals that in slum census 2014 about $52.5 \%$ of households get their drinking water from tube-well which is followed by $45.21 \%$ of households getting their drinking water from tap. Only $0.16 \%$ of households collect their drinking water from pond/ditches at national level. In city corporation areas most of the slum households $55.11 \%$ procure their drinking water from taps and $42.51 \%$ households get their drinking water from tube-well.

Table1: Percentage distribution of households of Slums by main sources of drinking water (Slum Census 2014)

\begin{tabular}{|c|c|c|c|c|c|c|c|}
\hline \multirow{2}{*}{ Locality } & \multicolumn{7}{|c|}{ Main Sources of Drinking Water (Percentages) } \\
\cline { 2 - 8 } & Total & $\begin{array}{c}\text { Tube- } \\
\text { well }\end{array}$ & Tap & Well & $\begin{array}{c}\text { Pond/ } \\
\text { Ditch }\end{array}$ & $\begin{array}{c}\text { Canal/ } \\
\text { River }\end{array}$ & Others \\
\hline $\begin{array}{c}\text { City } \\
\text { Corporations }\end{array}$ & $100 \%$ & 42.51 & 55.11 & 0.48 & 0.13 & 0.11 & 1.65 \\
\hline Municipalities & $100 \%$ & 87.54 & 10.30 & 0.52 & 0.27 & 0.78 & 0.59 \\
\hline Other urban & $100 \%$ & 44.68 & 53.34 & 1.30 & 0.21 & 0.07 & 0.39 \\
\hline National & $100 \%$ & 52.48 & 45.21 & 0.53 & 0.16 & 0.26 & 1.35 \\
\hline
\end{tabular}

\section{METHODOLOGY AND STUDY AREA}

An inception report has been prepared based on the initial discussion with various stakeholders for outlining the scope of the work and the major information requirement for the study. various relevant reports, project documents, existing literature have been reviewed and consulted. Interviews/discussions have been done with important stakeholders including NGOs, development partners, and Government officials. Korail slum and Geneva Camp slum have been randomly selected to investigate water supply and to collect drinking water samples. The samples have been tested in the Environmental Engineering Laboratory of Stamford University Bangladesh.

Korail and Geneva Camp slums are under Gulshan and Cantonment Thana. Both the slums are densely populated, and the inhabitants are not enjoying the all the urban facilities especially service facilities. The Dhaka Water Supply and Sewerage Authority (DWASA) is the responsible institution for water supply and sanitation of Dhaka city. Photos 1 and 2 show the location of the slums on satellite image. Photos 3 and 4 show some activities of water related works in the slums.

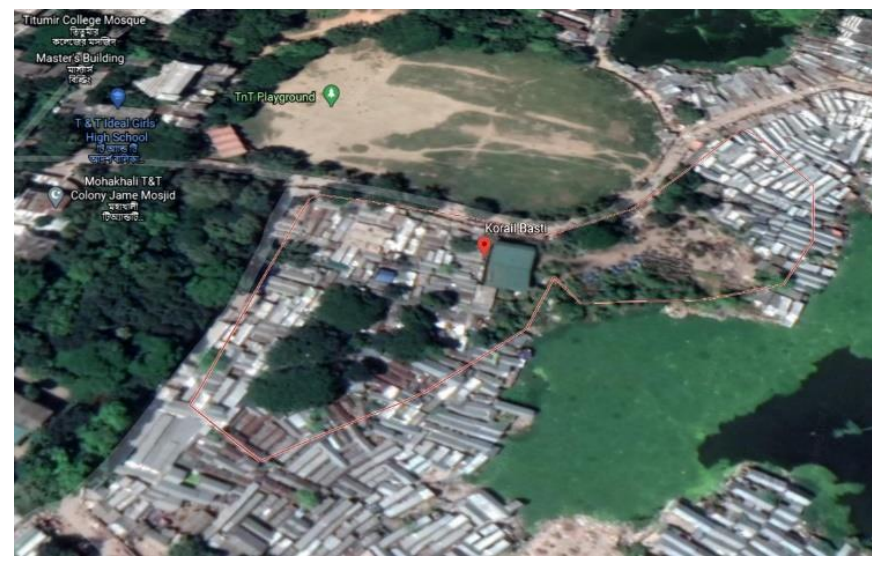

Photo 1: Satellite image showing the location of Korail Slum

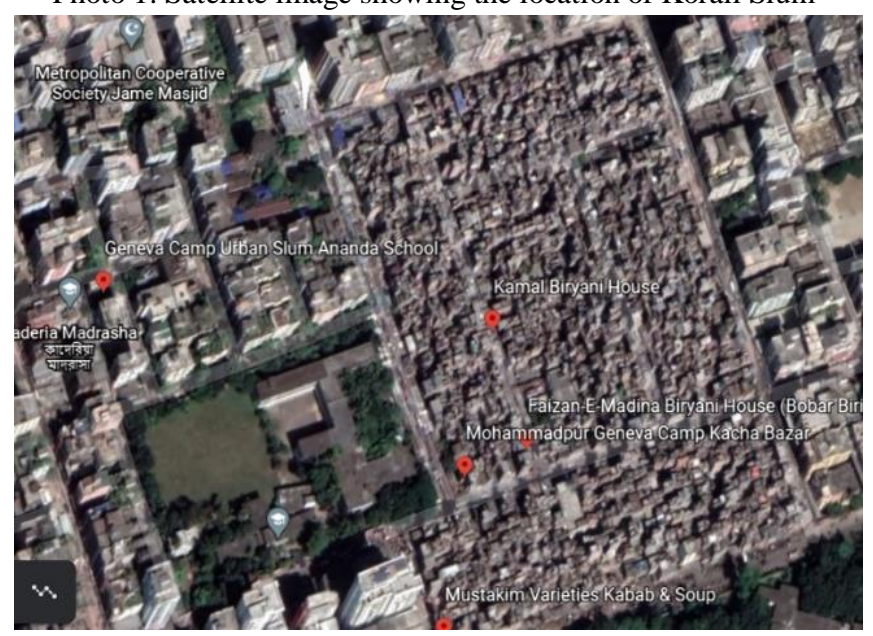

Photo 2: Satellite image showing the location of Geneva Camp Slum

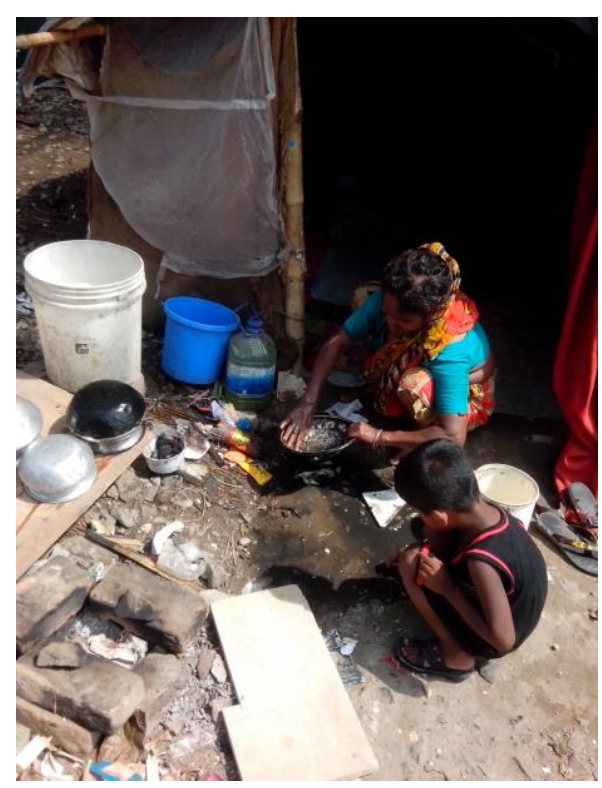

Photo 3: Cleaning Activities in Korail Slum 


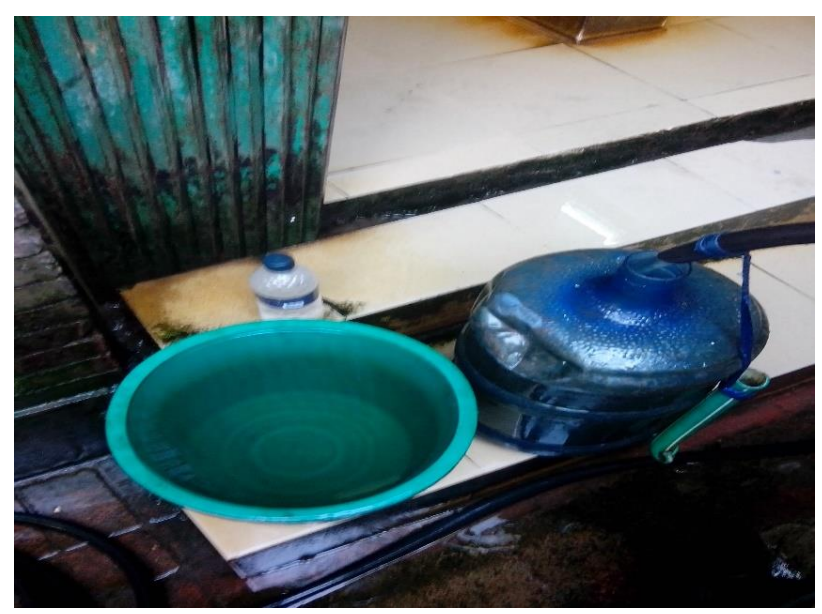

Photo 4: Drinking Water Storage in Geneva Camp Slum

\section{EXPERIMENT AND RESULTS}

To confer safety of water, the World Health Organization (WHO) has already taken initiatives in Bangladesh to promote preventive approaches for water quality management using Water Safety Plans (WSP) and support the development of appropriate sanitation technologies for flood and other disasterprone areas, including ecological sanitation (WHO, 2008). Correct determination of chemical (Photo 5) and microbiological ((Photo 6) quality of water is essential to ensure safety of drinking water across the country. The overall chemical and microbiological quality of drinking water randomly collected from two selected slums of Dhaka city in both qualitative and quantitative means. The Chemical properties of Drinking water is shown in Table 1

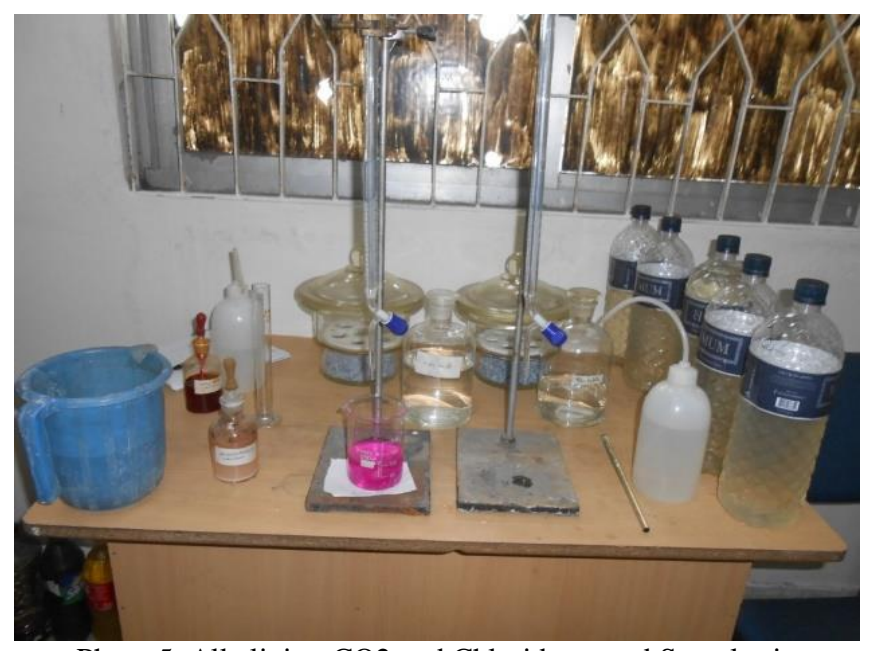

Photo 5: Alkalinity, CO2 and Chloride test od Samples in Environmental Engineering Laboratory

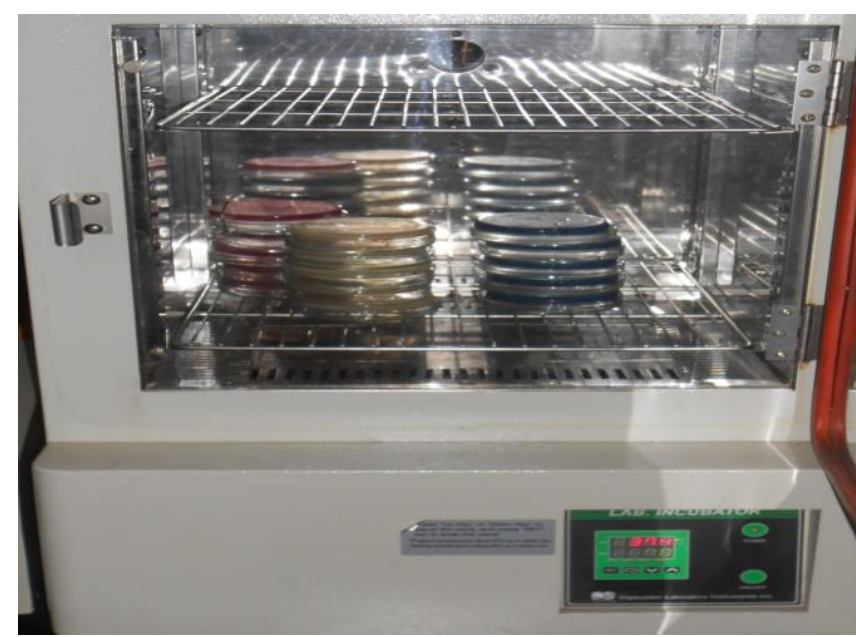

Photo 6: Microbiological Test of the Samples in Laboratory

It has been detected from Table 1 that $\mathrm{pH}$ of source water consumed by people of slums were in between the drinking water standard, 6.5 to 8.5 provided by Bangladesh Environment Conservation Rules (ECR 1997). All the collected water samples had hardness values in between the standard level. ECR' 97 has not set any standard of Carbon-dioxide for drinking water (Chowdhury et. al. 2017). Concentrations of Carbon-di-oxide in the samples were in the range of $22-40 \mathrm{mg} / \mathrm{l}$. Refer to Figure 2, Turbidity level of all water samples were satisfactory (0.4-3.1 NTU) and were below $10 \mathrm{NTU}$, the standard level given by ECR. Refer to Figure 1, Chloride at a concentration above $250 \mathrm{mg} / \mathrm{l}$ conveys salty taste to water and becomes objectionable to the consumer. Drinking water standard of chloride is in the range of 150 to $600 \mathrm{mg} / \mathrm{l}$. The Chloride concentrations of all collected water samples were low and below the standard range. In spite of having little public health significance of alkalinity in water, higher concentration of alkalinity in water is usually unpalatable. There was very little fluctuation of the values of alkalinity starting from 40 to $115 \mathrm{mg} / \mathrm{l}$ in the water samples collected in this study from different locations. ECR 1997 has not prescribed any standard of alkalinity for drinking water in Bangladesh.

Table 1: Chemical Properties of Samples of Drinking Water

\begin{tabular}{|c|c|c|c|c|c|c|c|c|}
\hline Area & $\begin{array}{l}\dot{0} \\
z \\
\frac{0}{z} \\
\bar{\Xi} \\
\tilde{n}\end{array}$ & $\frac{\pi}{2}$ & 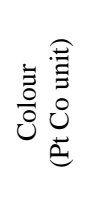 & 鸹 & 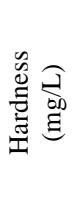 & 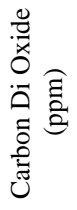 & 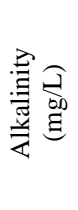 & 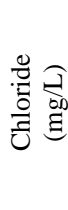 \\
\hline \multirow{3}{*}{$\begin{array}{l}\text { Korail } \\
\text { Slum }\end{array}$} & KS 01 & 6.7 & 53 & 1.4 & 4 & 25 & 63 & 9 \\
\hline & KS 02 & 6.5 & $\begin{array}{l}\text { Under } \\
\text { range }\end{array}$ & 1.3 & 4 & 35 & 110 & 17 \\
\hline & KS 03 & 6.7 & 54 & 3.1 & 2 & 48 & 101 & 95 \\
\hline
\end{tabular}


International Journal of Engineering Applied Sciences and Technology, 2021

Vol. 5, Issue 9, ISSN No. 2455-2143, Pages 66-70

Published Online January 2021 in IJEAST (http://www.ijeast.com)

\begin{tabular}{|c|c|c|c|c|c|c|c|c|}
\hline & KS 04 & 6.7 & $\begin{array}{l}\text { Under } \\
\text { range }\end{array}$ & 0.9 & 4 & 23 & 44 & 11 \\
\hline & KS 05 & 6.6 & 11 & 0.6 & 6 & 25 & 110 & 75 \\
\hline \multirow{5}{*}{$\begin{array}{c}\text { Geneva } \\
\text { Camp } \\
\text { Slum }\end{array}$} & GC 01 & 6.4 & 2 & 0.9 & 2 & 22 & 55 & 9 \\
\hline & GC 02 & 6.6 & $\begin{array}{l}\text { Under } \\
\text { range }\end{array}$ & 1.2 & 2 & 37 & 112 & 50 \\
\hline & GC 03 & 6.7 & $\begin{array}{l}\text { Under } \\
\text { range }\end{array}$ & 0.6 & 8 & 25 & 40 & 75 \\
\hline & GC 04 & 6.2 & $\begin{array}{l}\text { Under } \\
\text { range }\end{array}$ & 0.4 & 0 & 42 & 50 & 65 \\
\hline & GC 05 & 6.5 & 7 & 0.5 & 3 & 40 & 85 & 60 \\
\hline
\end{tabular}

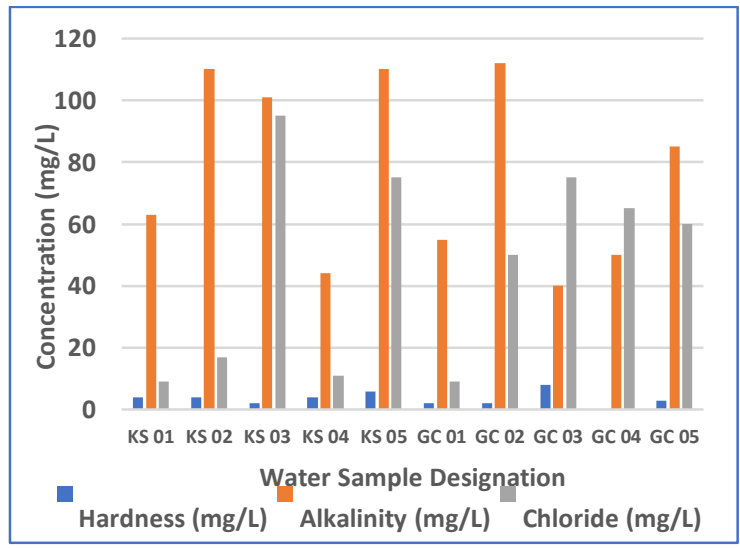

Figure 1: Hardness, Alkalinity and Chloride Concentration of Drinking Water

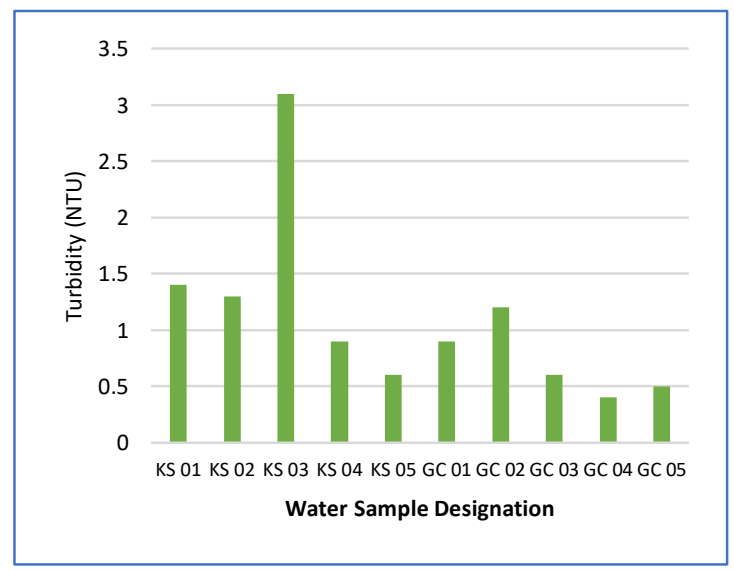

Figure 2: Turbidity of Drinking Water

Table 2: Microbiological Properties of Samples of Drinking Water

\begin{tabular}{|c|c|c|c|c|c|c|c|c|}
\hline & 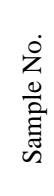 & 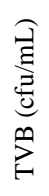 & 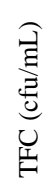 & 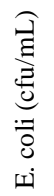 & 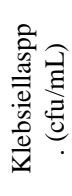 & 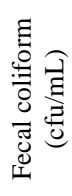 & 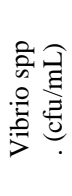 & 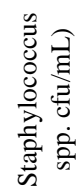 \\
\hline
\end{tabular}

\begin{tabular}{|c|c|c|c|c|c|c|c|c|}
\hline \multirow{5}{*}{ 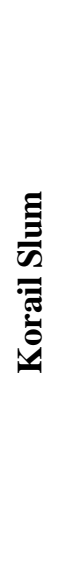 } & $\begin{array}{l}\overline{0} \\
\tilde{y}\end{array}$ & $\begin{array}{l}\stackrel{0}{0} \\
x \\
\text { a } \\
\text { in }\end{array}$ & 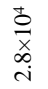 & $\begin{array}{l}\frac{\partial}{x} \\
\underset{j}{\text { ja }}\end{array}$ & 0 & 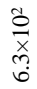 & 0 & $\begin{array}{l}\text { oे } \\
\text { x } \\
\text { fo }\end{array}$ \\
\hline & $\begin{array}{l}\tilde{\delta} \\
\tilde{y} \\
\tilde{y}\end{array}$ & $\begin{array}{l}d \\
\text { x } \\
\text { or. } \\
\text { in }\end{array}$ & 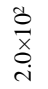 & 0 & 0 & 0 & 0 & 0 \\
\hline & $\begin{array}{l}\tilde{0} \\
\hat{y}\end{array}$ & $\begin{array}{l}n \\
x \\
n \\
n \\
n\end{array}$ & $\begin{array}{l}\frac{3}{x} \\
\text { a } \\
\text { i }\end{array}$ & 0 & $\frac{\partial}{\frac{\partial}{a}}$ & 0 & 0 & $\begin{array}{l}\vec{d} \\
\underset{x}{x} \\
\stackrel{y}{+}\end{array}$ \\
\hline & $\begin{array}{l} \pm \\
0 \\
\tilde{y}\end{array}$ & $\begin{array}{l}\tilde{\partial} \\
\vec{x} \\
\dot{d} \\
\text { in }\end{array}$ & 0 & 0 & 0 & 0 & 0 & $\begin{array}{l}\overrightarrow{0} \\
\stackrel{x}{x} \\
\text { in }\end{array}$ \\
\hline & $\begin{array}{l}\tilde{z} \\
\tilde{y} \\
\tilde{y}\end{array}$ & $\begin{array}{l}\stackrel{3}{x} \\
\stackrel{n}{x} \\
\end{array}$ & $\begin{array}{l}\overrightarrow{0} \\
\vec{x} \\
0 \\
\infty\end{array}$ & $\begin{array}{l}\stackrel{\partial}{x} \\
\underset{x}{x} \\
\text { i }\end{array}$ & 0 & $\begin{array}{l}\vec{D} \\
\underset{\sim}{x} \\
\end{array}$ & $\begin{array}{l}\vec{y} \\
\vec{x} \\
n \\
\infty\end{array}$ & $\begin{array}{l}\overline{0} \\
\underset{\infty}{0} \\
\text {. }\end{array}$ \\
\hline \multirow{5}{*}{ 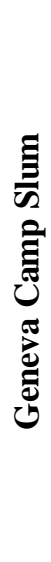 } & $\begin{array}{l}\overline{0} \\
0 \\
0\end{array}$ & $\begin{array}{l}\frac{8}{0} \\
x \\
m \\
b\end{array}$ & $\begin{array}{l}\stackrel{3}{x} \\
\stackrel{x}{x}\end{array}$ & 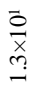 & $\stackrel{\vec{x}}{\underset{x}{*}}$ & 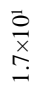 & $\begin{array}{l}\bar{\partial} \\
\stackrel{x}{x} \\
\stackrel{n}{n}\end{array}$ & $\begin{array}{c}\stackrel{\partial}{\vec{x}} \\
\stackrel{-}{=}\end{array}$ \\
\hline & $\begin{array}{l}\text { Oे } \\
\text { U }\end{array}$ & $\begin{array}{l}8 \\
\text { x } \\
\stackrel{+}{i} \\
\text {. }\end{array}$ & $\begin{array}{l}\frac{3}{x} \\
\stackrel{x}{-}\end{array}$ & 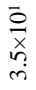 & 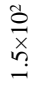 & $\begin{array}{l}\overrightarrow{0} \\
\times \\
\infty \\
i\end{array}$ & 0 & $\begin{array}{l}\overrightarrow{0} \\
\stackrel{x}{x} \\
\text { r }\end{array}$ \\
\hline & 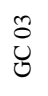 & $\begin{array}{l}0 \\
0 \\
0 \\
0 \\
0\end{array}$ & 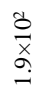 & 竞 & $\begin{array}{l}\stackrel{\vec{\partial}}{\vec{x}} \\
\stackrel{i}{i}\end{array}$ & $\begin{array}{l}\stackrel{0}{\vec{x}} \\
\underset{j}{\mathrm{j}}\end{array}$ & 0 & $\begin{array}{l}\overrightarrow{0} \\
\vec{x} \\
\dot{m}\end{array}$ \\
\hline & $\begin{array}{l}\text { ¿ } \\
\text { U }\end{array}$ & $\begin{array}{l}0 \\
\vec{x} \\
0 \\
0 \\
\sigma\end{array}$ & $\begin{array}{l}\tilde{\partial} \\
\underset{x}{x} \\
\stackrel{n}{-}\end{array}$ & 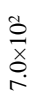 & $\begin{array}{l}\vec{\partial} \\
\vec{x} \\
\stackrel{+}{*}\end{array}$ & $\begin{array}{l}\stackrel{\bar{O}}{x} \\
\stackrel{x}{-}\end{array}$ & $\begin{array}{l}\vec{\partial} \\
\vec{x} \\
\dot{m}\end{array}$ & $\begin{array}{l}\overrightarrow{0} \\
\vec{x} \\
\dot{b}\end{array}$ \\
\hline & $\begin{array}{l}n \\
0 \\
0\end{array}$ & $\begin{array}{l}\text { a) } \\
x \\
\infty \\
i \\
\text { in }\end{array}$ & $\begin{array}{l}\tilde{c}_{0} \\
\underset{\mathbf{x}}{0} \\
\dot{m}\end{array}$ & 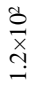 & $\begin{array}{l}\underset{0}{x} \\
\stackrel{0}{+}\end{array}$ & 0 & 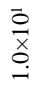 & $\frac{\overline{0}}{x}$ \\
\hline
\end{tabular}

From Table 2 and Figure 3 out all the samples of Geneva Camp slum and two samples of Korail Slum show presence of coliform bacteria whereas the drinking water standard of fecal and total coliform is zero in Bangladesh (ECR 1997). The samples also show different microorganism presence in the samples.

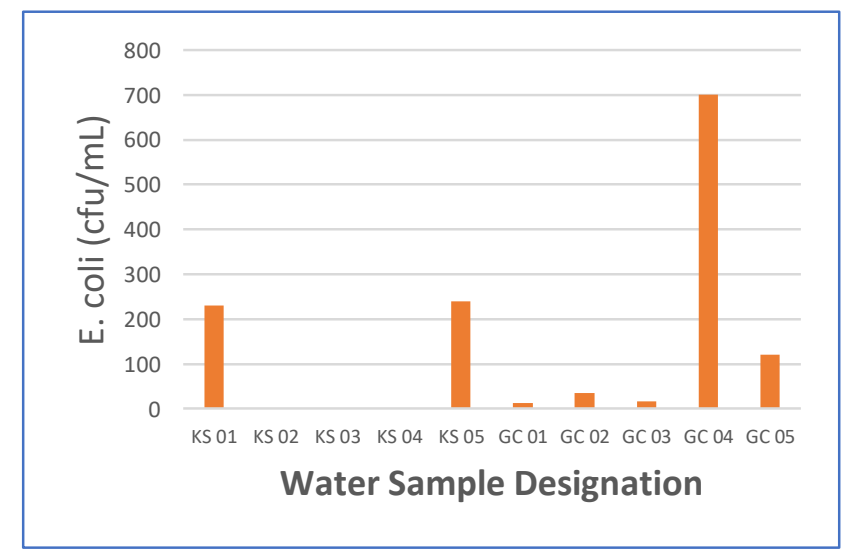

Figure 3: Presence of Coliform Bacteria in Drinking Water 


\section{International Journal of Engineering Applied Sciences and Technology, 2021 \\ Vol. 5, Issue 9, ISSN No. 2455-2143, Pages 66-70 \\ Published Online January 2021 in IJEAST (http://www.ijeast.com)}

\section{CONCLUSION}

The level of safe drinking water practice has been found to be extensively low among the slum dwellers. Most of the slum people use tube well water and supplied water by DWASA for drinking. It is observed that houses, shops, drains, roads etc. have been constructed in unplanned manner and solid wastes are stored on open places in the slum areas. For lack of sufficient water sources, most people resort to unsafe water sources like ponds, rivers and even ditches which cause sufferings from diseases.

On the basis of findings, the following recommendations may be suggested

- Currently, the slum areas are unplanned and are in environmentally hazardous conditions. So, in the slum areas, planned low-cost structures should be built and safe and pure drinking water should be ensured by DWASA to give the slum population base a healthy living environment. Because this is the proper time to take steps for making a well-planned city.

- Initiatives for private and NGOs participation should be promoted in the distribution of water to the low-income slum communities. Again, NGOs should be encouraged and offered the best facilities for taking more programs in slum area for ensuring safe drinking water.

- Enthusiastic hygiene education program should be imparted to slum dwellers and social mobilization programmes should be undertaken to make people aware of the bad effects of unhygienic situations.

- Finally, there should be a coordinated plan considering all the stakeholders like Government, Dhaka North City Corporation, DWASA, NGOs, the slum dwellers, environmental conservation groups and service providers to authorize the activities of different stakeholders for improving overall development programmmes of the slums.

\section{REFERENCE}

[1] Badhan, M. A., Roy B. and Sifat S. A. (2017). Water supply and sanitation situation of Kalyanpur slum area in Dhaka International Journal of Natural and Social Sciences, 2017, 4(2): (pp.54-59).

[2] Amin A.T.M.N. (1991). Dhaka's informal Sectors and its role in the transmission of Bangladesh economy, Dhaka Past Present Future, Asiatic Society of Bangladesh, Dhaka. (pp.446-470).

[3] Capacity Building Service Group (CBSG). (2010). Ensuring Services to Slum Dwellers Dhaka, Water Service Delivery, Organisation for Low Income and Slum Community, WASA (pp. 5-20).

[4] Chowdhury, F, Dey P. and Ahmed, T. (2017). Assessment of Drinking Water Quality Consumed by Floating People in Dhaka City, Bangladesh, International Journal of
Innovative Research in Science, Engineering and Technology, Vol. 6, Issue 3, March 2017 (pp. 3091-3098).

[5] CUS (Centre for Urban Studies). (1979). The Urban Poor in Bangladesh, Dhaka.

[6] CUS (Centre for Urban Studies). (1993). Survey of Slums in Dhaka Metropolitan Area-1991, Dhaka, \& Hossain S. (1992). Research on slums and squatters in Bangladesh: a critical review' in Social Science Review, Vol.18, no.2, (pp.67-76).

[7] CUS (Centre for Urban Studies). (1996). Survey of Slums and Squatter Settlements in Dhaka City., Dhaka.

[8] ECR. (1997). The Environment Conservation Rules. Ministry of Environment and Forest, Government of the People's Republic of Bangladesh, (pp. 179-227).

[9] Fariduddin K.M. and Khan A.U., (1996). Health profile of the urban poor, Urban Poor in Bangladesh, Centre for Urban Studies, Dhaka.

[10] Islam N., Huda N., Narayan F.B. and Rana P.B. (1997). Addressing the Urban Poverty Agenda in Bangladesh, University Press Limited, Dhaka. (pp. 12-28).

[11] Rahaman, M.M. (2012). Water Wars in 21st Century: Speculation or Reality? International Journal of Sustainable Society, 4(1/2): 3-10. DOI:10.1504/IJSSOC.2012.044658.

[12] United States Agency for International Development (USAID) (1999). Environmental Mapping and Workbook for Khulna City, USAID, Dhaka.

[13] UN (United Nations) (2012). World Urbanization prospects, United Nations Department of Economic, Social Affairs Population Division. New York, USA.

[14] WHO (World Health Organization). 2008. Guidelines for Drinking Water Quality. WHO, Geneva, Switzerland.

[15] World Health Organization (2000). Guidelines for Drinking-Water Quality, 1, Recommendations, 3rd edition, Geneva. ISBN 9251546387. 